\title{
Pesticide Residue and Health Risk Analysis of Six Commonly Used Herbal Medicinal Products in Kumasi, Ghana
}

\author{
Article by Frank Adusei-Mensah ${ }^{1}$, Isaac Tabiri Henneh ${ }^{2}$ and Martins Ekor ${ }^{3}$ \\ ${ }^{1}$.School of Public Health, Texila American University, Guyana \\ ${ }^{2,3}$ Department of Pharmacology, School of Medical Sciences, University of Cape Coast, Cape \\ Coast, Ghana \\ E-mails: martins.ekor@ucc.edu.gh ${ }^{3}$
}

\begin{abstract}
Background: Ghana does not have reliable surveillance programme for ensuring safety of food and herbal products on the market. Data from previous studies have shown the presence of pesticide residues in food products and its associated health risk. In this present study we assessed the residual pesticide content of six most patronized herbal preparations in Kumasi, Ghana and the attendant risk of such contamination to public health.

Methodology: The herbal preparations were cleaned up using Quick, Easy, Cheap, Effective, Rugged, and Safe (QuEChERS) method for insecticide analysis. Analysis was carried out on GC-MS using 33 external standards.

Results: The total pesticide content in most of the herbal preparations was below the maximum residue limit (MRL). However, the concentration of pirimiphos-methyl in herbal product ' $E$ ' (HPE) $(0.082 \mathrm{mg} / \mathrm{kg})$ was higher than the MRL $(0.05 \mathrm{mg} / \mathrm{kg})$. In addition, the hazard indices' (HI) for five herbal products were less than ' 1 ' and safe for consumption without any possible future health risk. However, the HI for HPE was determined to be greater than '1'. Aldrin, dieldrin and chlordane which are banned in Ghana were also identified in $50 \%$ of the studied herbal preparations.

Conclusion: Data from this study reveals that HPE is contaminated with pirimiphos-methyl pesticide and unsafe for consumption. Also, the presence of banned pesticides in 50\% of the studied herbal preparations calls for concern and urgent intervention by relevant regulatory authorities.
\end{abstract}

Keywords: Herbal medicinal preparation, hazard index, pesticides, contamination, health risk, safety.

\section{Introduction}

Close to $80 \%$ of the Ghanaian population rely on the herbal medicines (HM) for their basic health needs. They (HMs) are used to cure minor ailments, treat chronic diseases and for preventive purposes. Pesticide-contaminated herbal preparations may have detrimental effects and it belittles the intended health benefits of the herbal product. Population growth has resulted in increased use of pesticides to increase crop yield, reduce post-harvest and storage losses and increase shelf life of farm produce, (Chouaïbou et al., 2016; Johnson et al., 2013). Residual pesticides may end up in the tissues of these medicinal plants. Elevated pesticide residues in medicinal plants is, therefore a major health concern, (Obiri-Danso et al., 2011). Though in Ghana, most herbal medicinal materials are obtained from medicinal plants grown in the wild, research has shown that pesticide uptake by non-targeted plants through indirect pesticide application is significant, (Essumang et al., 2013).

Pesticide residues in herbal products and other food stuff on the Ghanaian market are poorly monitored. There is also apparently no regular surveillance programme to regularly monitor the residual pesticide content in food and multiherbal products on the market putting the health of the Ghanaian populace at pesticide contamination health risk. In addition, there is also currently no published work on pesticide residues in herbal preparations in Ghana, as a result, residual pesticide data on herbal preparations in Ghana are lacking. The few published studies from the Ghanaian context were cited on vegetables (Amoah et al., 2006; Darko and Akoto, 2008; Osei-Fosu et al., 2014; Akoto et al., 2015a), fruits, (Fosu et al., 2017), beans (Di Bella et al., 2017), cereals (Akoto et al., 2015b), honey (Darko et al., 2017), fishes (Kuranchie-Mensah et al., 2013) and dairy products (Darko and Acquaah, 2008). Most of these studies suggested pesticide contamination health risk to 
DOI: $10.21522 /$ TIJPH.2013.06.03.Art018

ISSN: $2520-3134$

consumers. Though studies on residual pesticide content on herbal preparations have been published in some European, Asian and American countries, geographical, exposure, and other variations in anthropogenic activities makes it not generalizable to the herbal products on the Ghanaian market, (Naithani and Kakkar, 2004; Oh, 2009; Mosaddegh et al., 2014; Yang et al., 2017). It is imperative, therefore, that herbal medicinal products on the Ghanaian market are regularly monitored to assess possible contamination and health risk and ensure public safety. The main aim of this study, therefore, is to determine the pesticide content and assess the human health risk of the six-most patronized herbal medicinal products on the Kumasi market of Ghana.

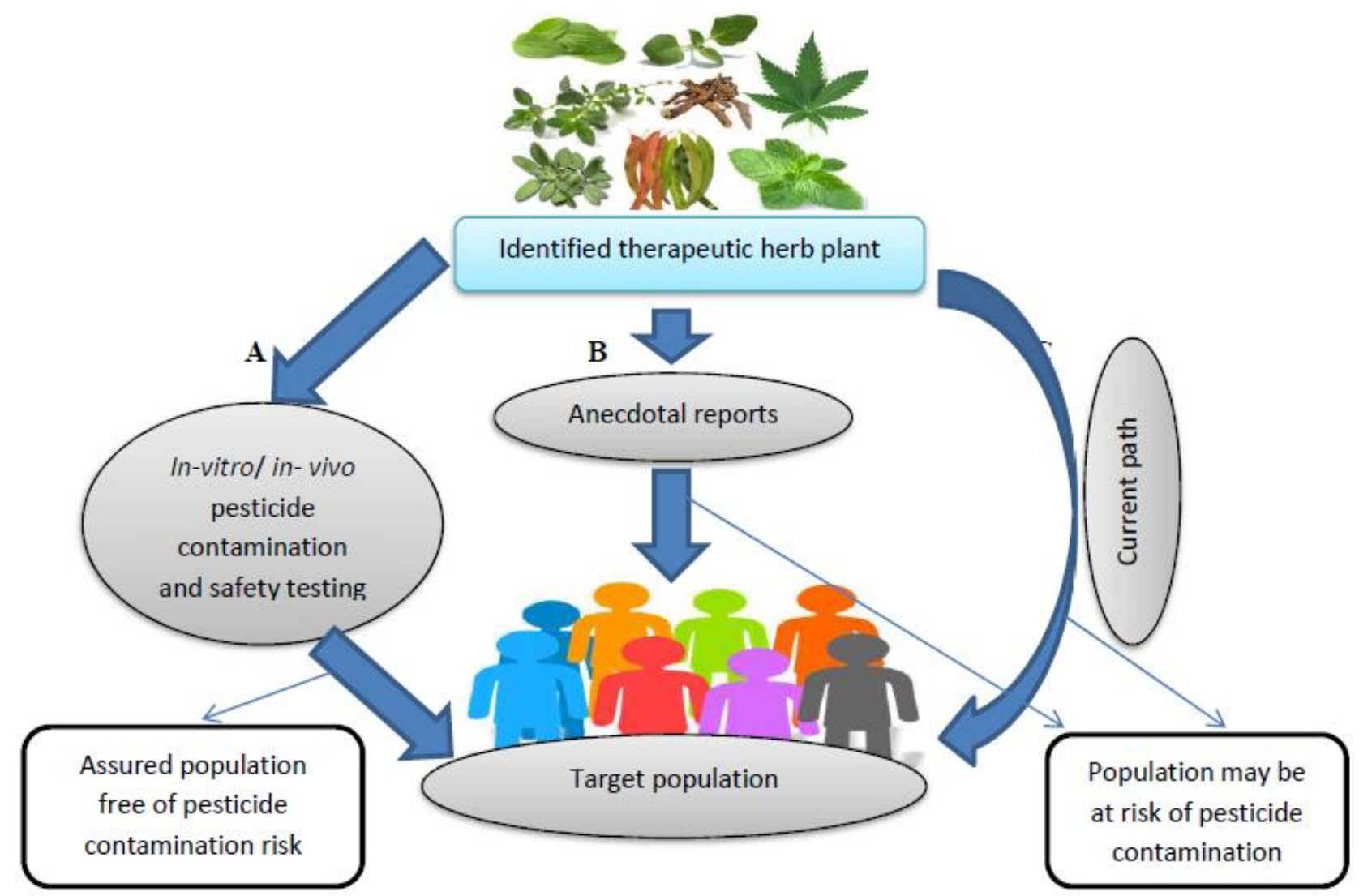

Figure 1. Schematic route of herbal medicine from field identification to target population for human consumption.

Path ' $\mathrm{A}$ ' is the recommended scientific path, but paths ' $\mathrm{B}$ ' and ' $\mathrm{C}$ ' are the observed paths for most HMPs in Ghana these days. Most herbal materials and products are not tested for pesticide contamination before they reach the target population in Ghana. The dominant paths currently in Ghana are the paths ' $B$ ' and ' $C$ ' which put the population at risk of possible pesticide contamination and health risk. Path 'A' which is scientifically recommended path is somehow rarely used by few herbal companies in the country. 
Methodology

Sample selection

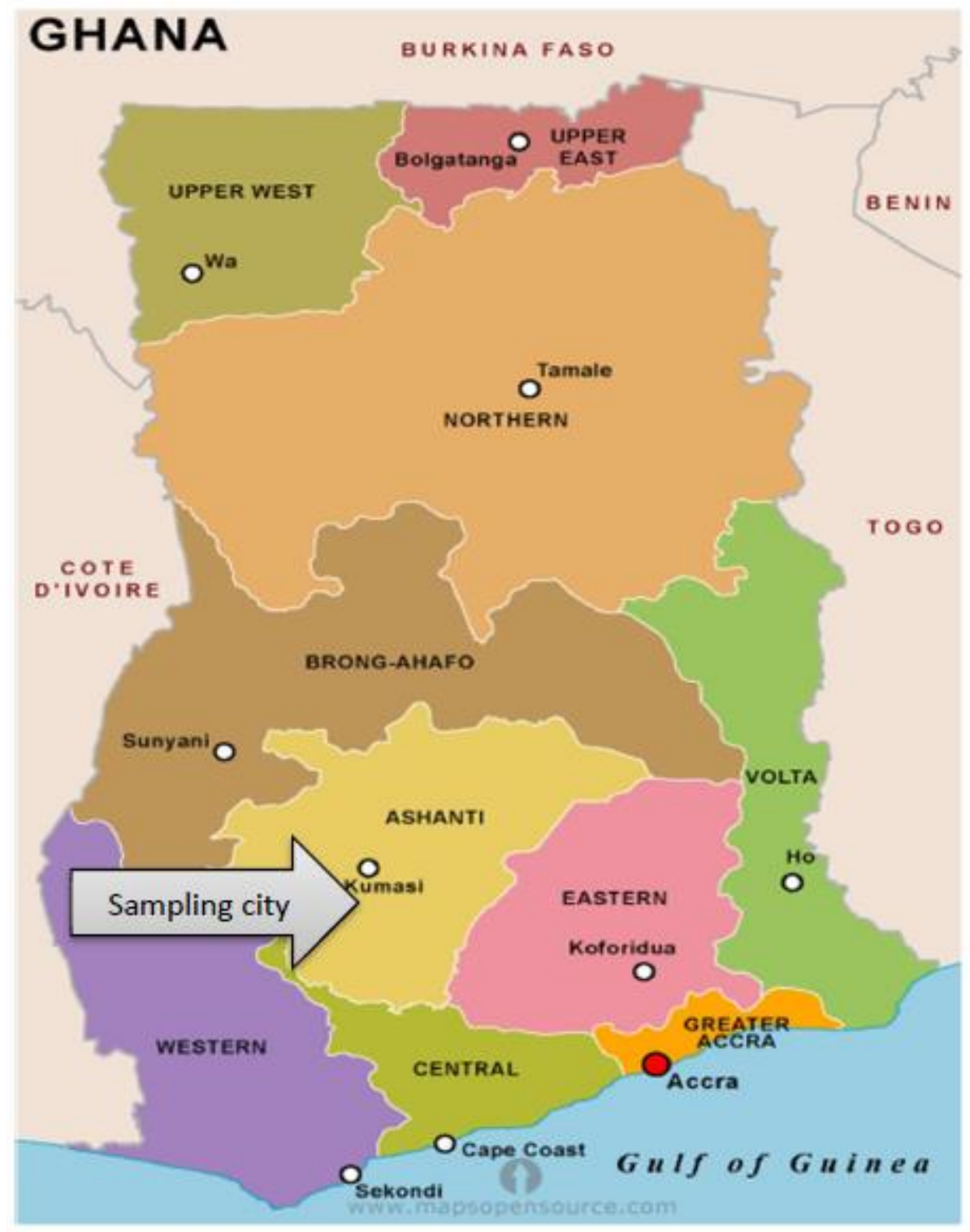

Figure 2. Pictorial map of Ghana showing the sampling city

A mini survey was carried out among some randomly selected herbal medicine users and pharmacy shops that also sell herbal medicine on wholesale or retail. The mini survey was carried out in Kejatia, Bantama and Ashtown districts in the Kumasi Metropolis of Ghana, (Fig. 2). Herbal medicine users were asked about the anti-malarial, anti-hypertensive and anti-diabetic herbal medicinal products they go for when unwell. Also, the wholesale and retail pharmacy shops involved in the study were asked about the most patronized antimalarial, anti-diabetic and anti-hypertensive HMPs in their collections. The list was compiled and tallied. The top 3 antimalarial, top 2 anti-diabetics and the top 1 antihypertensive HMPs which were most patronized according to the survey data were selected for the pesticide study. The six HMPs investigated were Alive Diabalex Mixture ${ }^{\circledR}$ for diabetes, Osompa D.P. ${ }^{\circledR}$ for diabetes and high blood pressure, Time Herbal Mixture ${ }^{\circledR}$ for malaria, Tetewobika Garlic Bitters $^{\circledR}$ for hypertension, Adutwumwaa Malamix ${ }^{\circledR}$ for malaria and Taabea Herbal Mixture ${ }^{\circledR}$ for malaria. The six HMPs were randomly coded for ethical reasons and henceforth shall be represented by their random codes; HPA, HPB...HPF. 
DOI: $10.21522 /$ TIJPH.2013.06.03.Art018

ISSN: $2520-3134$

\section{Extraction and clean-up of the liquid herbal mixtures for GC-MS pesticide analysis}

Herbal preparations were extracted in n-hexane-ethylacetate system (3:7) and clean-up using Quick, Easy, Cheap, Effective, Rugged, and Safe (QuEChERS) sample preparation method for GCMS multi-residue pesticide analysis. The procedure as described by Nguyen and Kimaru was applied (Kimaru, 2014). Standard pesticide solutions of 33 pesticides with known concentrations were used as external standards. Results were presented in chromatographs, tables and figures.

\section{Quality control parameters of the GC-MS}

The detector type of the GC-MS was set to 3800 (10 volts), Bus address was set to 44, channel was set to ECD, sample rate was set to $10 \mathrm{~Hz}$ and a run time of 32.968 minutes. A total of 33 external pesticide standards were used and the instrument was set to analysis mode. Pesticide content was calculated using peak area measurement and the offset time was set to 0.000 minutes. Duplicate injections were made at a delay time of 0.8 minutes.

\section{Health risk estimation}

\section{Estimated daily intakes (EDIs) of the pesticides identified in the herbal products}

The estimation of EDI of each of the identified pesticide present in the mixture was determined by the following equation, (Ou et al., 2016).

$$
E D I=\frac{E_{D} \times C}{W_{A B}}
$$

Identified pesticides present in the herbal preparations were compared to international acceptable reference dose levels. $\mathrm{EDI}=\left[\mathrm{C}\right.$ (content of pesticide) $\times \mathrm{E} \_$(daily dosage $\left.)\right] /(\mathrm{BW})$. BW is the Ghanaian average body weight; (65 kg adults, $24 \mathrm{~kg}$ children).(Ekhator et al., 2017; Ou et al., 2016). Estimated daily intake for Chlopyrifos is $0.1 \mathrm{mg} / \mathrm{kg} \mathrm{Bw}$ acute and $0.01 \mathrm{mg} / \mathrm{kg} \mathrm{Bw}$ chronic.(Skovgaard et al., 2017)

\section{Targeted hazard quotient (THQ)}

THQ for pesticide contaminants without established RfDo shall have their THQ estimated using the formula below. Where $\mathrm{C}$ is the concentration of the contaminant pesticide in the HMP $(\mathrm{mg} / \mathrm{kg})$, MRL is the maximum residual limit in $\mathrm{mg} \cdot \mathrm{kg}^{-1} \cdot \mathrm{day}^{-1}$.

$\mathrm{THQ}=\mathrm{C} / \mathrm{MRL}$

\section{Hazard index (HI)}

The chronic hazard index $(\mathrm{HI})$ is the sum of more than one hazard quotient for multiple toxicants. Harrison and Chirgawi, (Harrison and Chirgawi, 1989) reported that exposure to two or more pollutants may result in additive and/or interactive effects. THQs can be summed across constituent pesticides to generate a hazard index (HI) for an oi ${ }^{i}$ al dosage-pathway combination.

\section{Results and discussion}

$$
\mathrm{HI}=\sum_{n=1} \mathrm{THQn}
$$

The total pesticide content in most of the herbal preparations was below the MRL limit. However, the concentration of pirimiphos-methyl in HPE $(0.082 \mathrm{mg} / \mathrm{kg})$ was higher than the MRL limit $(0.05$ $\mathrm{mg} / \mathrm{kg}$ ). This means that HPE do not meet the legal requirements for pirimiphos-methyl to be on the market and used by patients and may pose health risk. 
Table 1. Pesticide residues detected and quantified from the herbal products

\begin{tabular}{|c|c|c|c|c|c|c|}
\hline Sample & Pesticide class & Pesticide name & $\begin{array}{l}\text { Conc. In } \\
\text { Sample } \\
(\mathrm{mg} / \mathrm{kg})\end{array}$ & $\begin{array}{l}\text { Retentio } \\
\text { n time }\end{array}$ & $\begin{array}{l}\text { Mean } \\
\text { Conc. } \\
\text { (mg/kg) } \\
\end{array}$ & MRLs \\
\hline HPA & $\begin{array}{l}\text { organophosphor } \\
\text { us }\end{array}$ & Chlorpyrifos & 0.022 & 10.72 & 0.022 & 0.05 \\
\hline \multirow[t]{2}{*}{ HPB } & $\begin{array}{l}\text { organophosphor } \\
\text { us }\end{array}$ & Chlorpyrifos & 0.01 & 10.715 & 0.01 & 0.05 \\
\hline & $\begin{array}{l}\text { organophosphor } \\
\text { us }\end{array}$ & Fenitrothion & 0.05 & 11.09 & 0.05 & 0.1 \\
\hline \multirow[t]{2}{*}{ HPC } & pirimiphos-m & pirimiphos-m & 0.008 & 10.486 & 0.008 & 0.05 \\
\hline & $\begin{array}{l}\text { organophosphor } \\
\text { us }\end{array}$ & Chlorpyrifos & 0.042 & 10.711 & 0.042 & 0.05 \\
\hline HPD & $\begin{array}{l}\text { organophosphor } \\
\text { us }\end{array}$ & Chlorpyrifos & 0.037 & 10.706 & 0.037 & 0.05 \\
\hline \multirow[t]{2}{*}{ HPE } & $\begin{array}{l}\text { organophosphor } \\
\text { us }\end{array}$ & pirimiphos-m & 0.082 & 10.476 & 0.082 & 0.05 \\
\hline & $\begin{array}{l}\text { organophosphor } \\
\text { us }\end{array}$ & Chlorpyrifos & 0.005 & 10.703 & 0.005 & 0.05 \\
\hline HPF & $\begin{array}{l}\text { organophosphor } \\
\text { us }\end{array}$ & Chlorpyrifos & 0.0175 & 10.702 & 0.0175 & 0.05 \\
\hline
\end{tabular}

Chlopyrifos pesticide was identified in all the six herbal products used in the study. This indicates that Chlopyrifos is a commonly used pesticide in Ghana. Though its' use is legal, care must be exercised during usage to reduce human exposure and health risk. Some legally banned pesticides in Ghana including Aldrin, dieldrin and chlordane, ("EPA Bans 25 Dangerous Agro-Chemicals," 2008) were also identified in $50 \%$ of the herbal products. This may indicate their continue use in the country despite the ban of their usage in the country Authorities are therefore called on to regulate their importation and usage in the country.

Table 2. Qualitatively Identified Pesticides from the herbal preparations

\begin{tabular}{|c|c|c|c|c|c|}
\hline HPA & HPB & HPC & HPD & HPE & HPF \\
\hline Chlopyrifos & Chlopyrifos & $\begin{array}{l}\text { gamma } \\
\mathrm{HCH}\end{array}$ & chlorpyrifos & Allethrin & gamma $\mathrm{HCH}$ \\
\hline & fenitrothion & aldrin & & heptachlor & heptachlor \\
\hline & & dieldrin & & Aldrin & chlorpyrifos \\
\hline & & \multicolumn{2}{|c|}{ lambda-cyhalothrin } & Permetrin & pirimiphos-m \\
\hline & & permitrin & & chlopyrifos & aldrin, \\
\hline & & \multicolumn{2}{|c|}{ pirimiphos-m } & pirimiphos & gamma chlordane \\
\hline & & \multicolumn{2}{|c|}{ Chlorpyrifos } & & dieldrin ppDDE \\
\hline & & & & & $\begin{array}{l}\text { lambda- } \\
\text { cyhalothrin }\end{array}$ \\
\hline & & & & & cypemethrin \\
\hline
\end{tabular}


DOI: $10.21522 /$ TIJPH.2013.06.03.Art018

ISSN: $2520-3134$

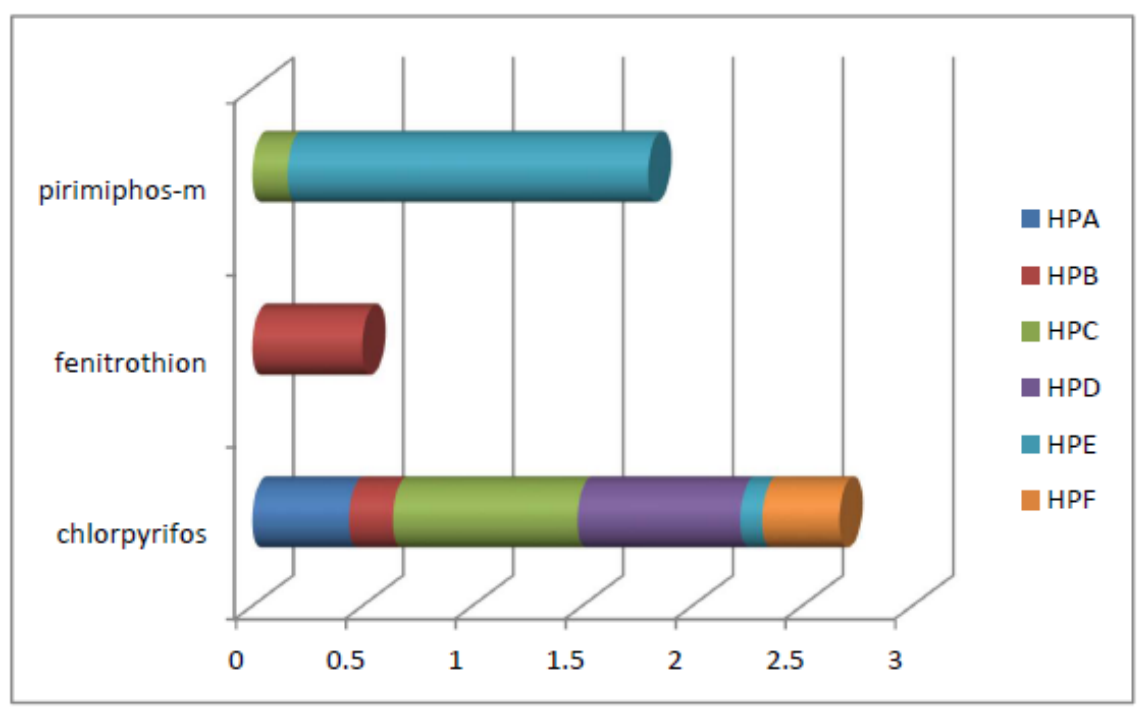

Figure 4. Pesticides quantitatively measured form HPs

Identification and quantitative estimations based on external stands were carried out on the pesticides. It was realized that pirimiphos-methyl was quantitatively identified in HPA and HPC, Fenitrothion in HPB only and chlopyrifos in HPA-HPF. Exposure to one or more of these pesticides at high concentrations has been associated with differing health conditions, (Ngoula et al., 2007). Fenitrothion has been reported to have toxic effects to the liver, brain, lung, and kidney, (AbdelGhany et al., 2016) Exposure to one or more of these pesticides should therefore be monitored to avoid any serious health problems.

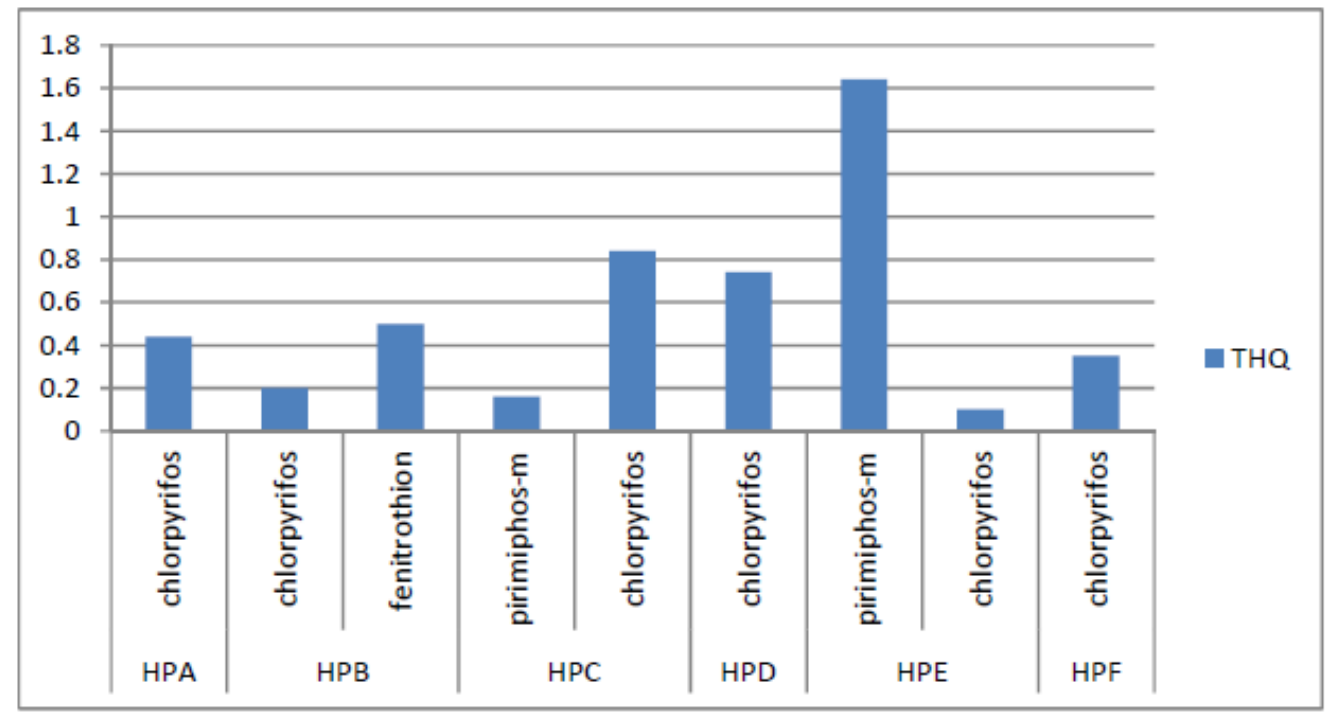

Figure 5. The targeted hazard quotient (THQ) of the individual pesticide present in the herbal products

THQ is used to express the health risk posed by a pesticide to a unit ' 1 '. If the THQ is equal to or higher than 1,(Wang et al., 2005) there is a potential health risk to the exposed population to the related pesticide and related interventions and protective measures needed to be taken to protect the population. In this study however, most of the THQ values for most of the pesticides were less than 1 . This indicates that the individual pesticides in the preparation do not pose health risk over the long term exposure to the herbal preparations. However, the THQ for pirimiphos-methyl for HPE was 1.6. This is far above the safe level of 1.0 and indicates that, the population administering HPE are at risk to pirimiphos-methyl risk over a long-term exposure. 


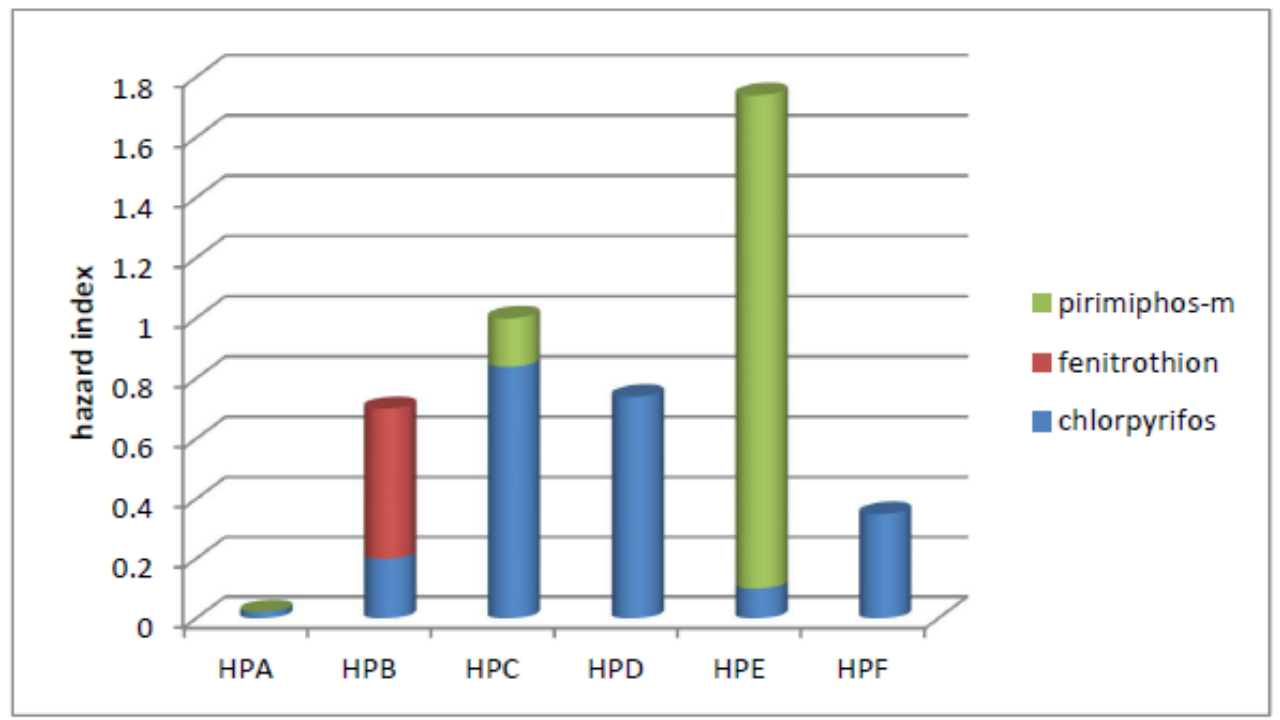

Figure 6. Hazard index (HI) of the pesticides present quantitatively in the herbal preparations

The chronic hazard index (HI) is the sum of more than one hazard quotient for multiple toxicants present in a herbal preparation. THQs can be summed across constituent pesticides to generate a hazard index (HI) for an oral dosage-pathway combination. The Total hazard risk of the herbal products based on pesticide contents were assessed and referenced to ' 1 '. If the HI value is less than 1 , the exposed population is unlikely to experience any adverse health hazard in their lifetime. However, if the THQ is equal to or higher than 1,(Wang et al., 2005) there is a potential health risk to the exposed population. The HI for all the herbal products was less than ' 1 ' and safe for consumption without any future health risk. But, the HI for HPE was greater than ' 1 ' probably due to the high pirimiphos-methyl content. This observation indicates the population using HPE are at risk of possible adverse health consequences due to long-term exposure to pirimiphos-methyl.

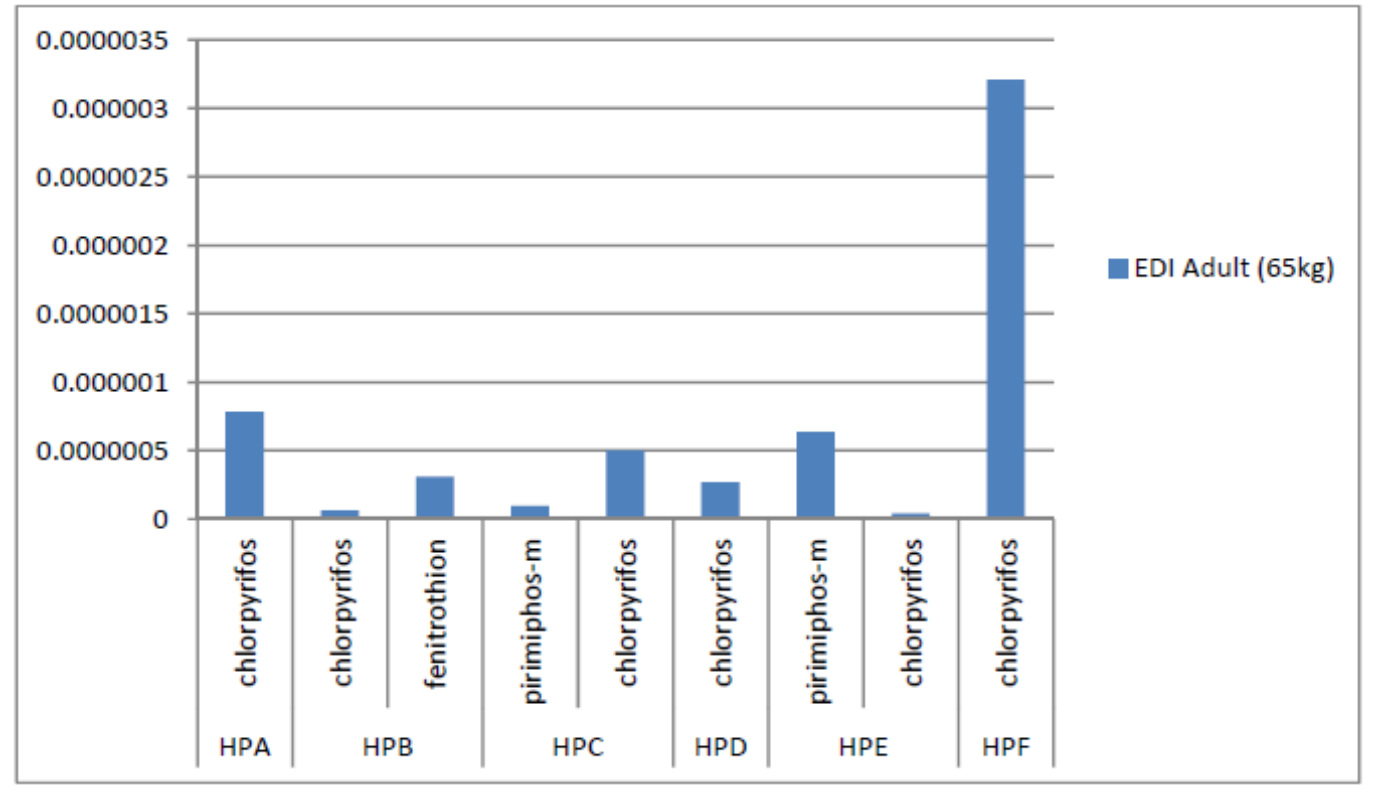

Figure 7. Adult estimated daily intakes (EDI) for the pesticides 
DOI: 10.21522/TIJPH.2013.06.03.Art018

ISSN: $2520-3134$

\section{Reference values}

\begin{tabular}{|l|l|l|}
\hline Pesticide & ARfD & ADI \\
\hline Chlopyrifos-methyl & $0.1 \mathrm{mg} / \mathrm{kg} \mathrm{bw}$ & $0.01 \mathrm{mg} / \mathrm{kg} \mathrm{bw} /$ day, (Pubchem, n.d.) \\
\hline Pirimiphos-methyl & $0.15 \mathrm{mg} / \mathrm{kg} \mathrm{bw}$ & $0.004 \mathrm{mg} / \mathrm{kg}$ bw/day, (Pubchem, n.d.) \\
\hline Fenitrithion & $0.013 \mathrm{mg} / \mathrm{kg} \mathrm{bw}$ & $0.005 \mathrm{mg} / \mathrm{kg} \mathrm{bw} /$ day, (Pubchem, n.d.) \\
\hline
\end{tabular}

The intake of the pesticides on the daily basis based on the dosage of the herbal preparations and the adult body weight was generally low. The EDI values were all below the international short-term oral reference dose limits for Chlopyrifos $(0.1 \mathrm{mg} / \mathrm{kg}$ bw), Pirimiphos-methyl $(0.15 \mathrm{mg} / \mathrm{kg} \mathrm{bw})$ and Fenitrothion $(0.013 \mathrm{mg} / \mathrm{kg} \mathrm{bw})$. This indicates that the intake of the herbal products based on the prescribed dosages on the product bottles may not pose any acute health risk. The intake concentrations were also within acceptable intake values; Chlopyrifos $(0.01 \mathrm{mg} / \mathrm{kg}$ bw/day), Pirimiphos-methyl (0.004 mg/kg bw/day) and Fenitrothion $(0.005 \mathrm{mg} / \mathrm{kg}$ bw/day). This observation indicates that intake of these herbal preparations under investigation may not pose any mid/ long-term health problems to the public.

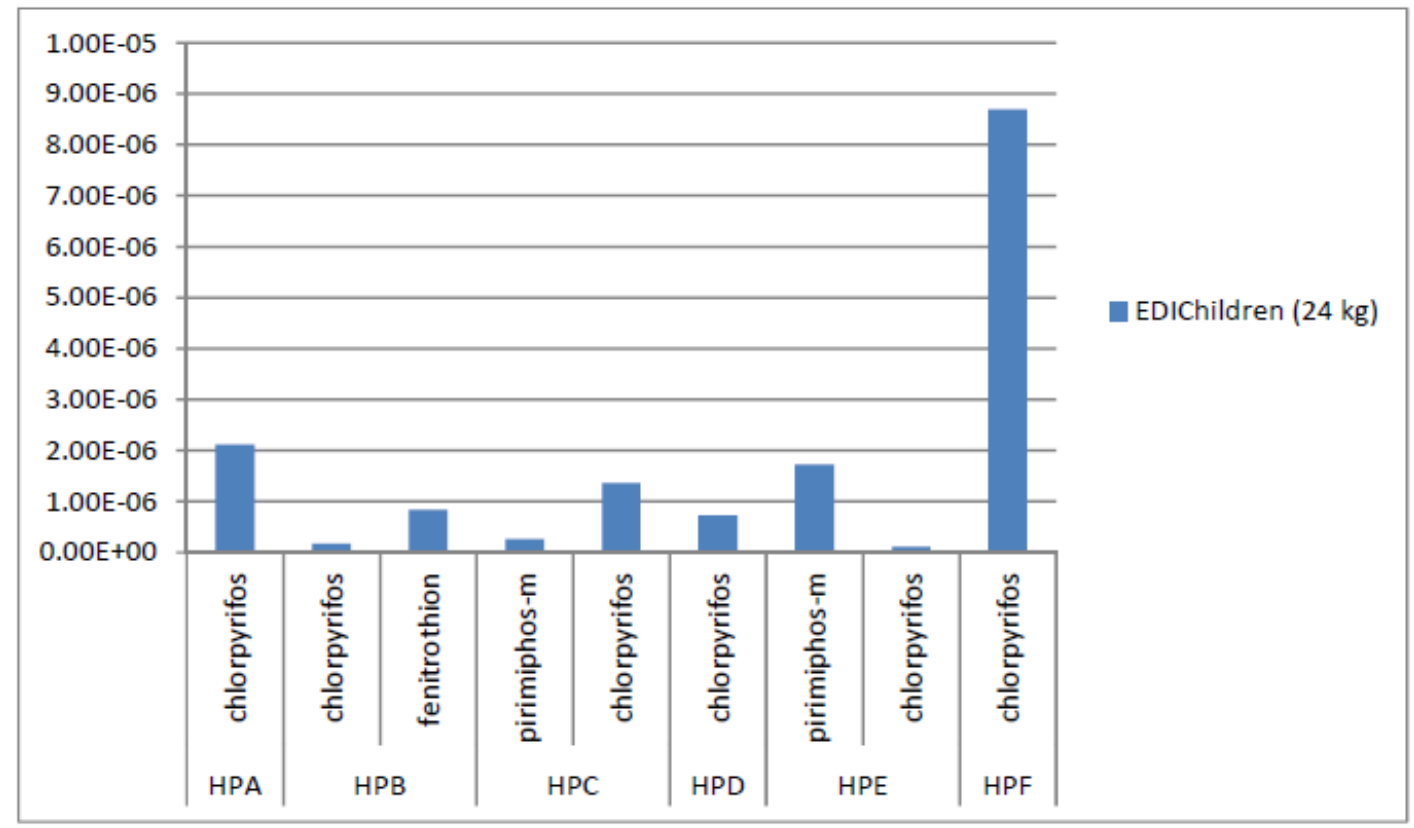

Figure 8. Estimated daily intakes (EDI) of the pesticides for Children

\section{Reference values}

\begin{tabular}{|l|l|l|}
\hline Pesticide & ARfD & ADI \\
\hline Chlopyrifos-methyl & $0.1 \mathrm{mg} / \mathrm{kg} \mathrm{bw}$ & $0.01 \mathrm{mg} / \mathrm{kg} \mathrm{bw} /$ day, (Pubchem, n.d.) \\
\hline Pirimiphos-methyl & $0.15 \mathrm{mg} / \mathrm{kg}$ bw & $0.004 \mathrm{mg} / \mathrm{kg}$ bw/day, (Pubchem, n.d.) \\
\hline Fenitrithion & $0.013 \mathrm{mg} / \mathrm{kg}$ bw & $0.005 \mathrm{mg} / \mathrm{kg}$ bw/day, (Pubchem, n.d.) \\
\hline
\end{tabular}

The child intake of the pesticides on the daily basis based on the dosage of the herbal preparations and the children's body weight $(24 \mathrm{~kg})$ was generally low. It was observed that, the intake concentrations were also within acceptable intake values; Chlopyrifos $(0.01 \mathrm{mg} / \mathrm{kg}$ bw/day), Pirimiphos-methyl $(0.004 \mathrm{mg} / \mathrm{kg}$ bw/day) and Fenitrothion $(0.005 \mathrm{mg} / \mathrm{kg}$ bw/day). This indicates that intake of these herbal preparations under investigation may not pose any mid/ long term health problems to the public. The EDI values were all below the international short-term oral reference dose limits for Chlopyrifos $(0.1 \mathrm{mg} / \mathrm{kg} \mathrm{bw})$, Pirimiphos-methyl $(0.15 \mathrm{mg} / \mathrm{kg}$ bw) and Fenitrothion $(0.013$ $\mathrm{mg} / \mathrm{kg} \mathrm{bw}$ ). This observation indicates that the intake of the herbal products based on the prescribed dosages on the product bottles may not pose any acute health risk. 


\section{Conclusion}

Except for HPE, the total pesticide content of the herbal preparations mostly patronized and used for managing malaria, diabetes and hypertension in Ghana was within internationally acceptable safety limits. The concentration of pirimiphos-methyl in HPE was higher than the MRL. Data from our study suggest that consumption of HPE may predispose to pirimiphos-methyl exposure and possible health hazard following chronic use of this herbal preparation. Similarly, some banned pesticides including Aldrin, dieldrin and chlordane were identified in 50\% of the studied herbal preparations. This should be of public health concern and therefore calls for urgent intervention by relevant regulatory authorities to forestall possible adverse health consequences.

\section{References}

[1]. Abdel-Ghany, R., Mohammed, E., Anis, S., Barakat, W., (2016). Impact of Exposure to Fenitrothion on Vital Organs in Rats [WWW Document]. J. Toxicol. https://doi.org/10.1155/2016/5609734.

[2]. Akoto, O., Gavor, S., Appah, M.K., Apau, J., (2015a). Estimation of human health risk associated with the consumption of pesticide-contaminated vegetables from Kumasi, Ghana. Environ. Monit. Assess. 187, 244. https://doi.org/10.1007/s10661-015-4471-0.

[3]. Akoto, O., Oppong-Otoo, J., Osei-Fosu, P., (2015b). Carcinogenic and non-carcinogenic risk of organochlorine pesticide residues in processed cereal-based complementary foods for infants and young children in Ghana. Chemosphere 132, 193-199. https://doi.org/10.1016/j.chemosphere.2015.02.056

[4]. Amoah, P., Drechsel, P., Abaidoo, R.C., Ntow, W.J., (2006). Pesticide and pathogen contamination of vegetables in Ghana's urban markets. Arch. Environ. Contam. Toxicol. 50, 1-6. https://doi.org/10.1007/s00244004-0054-8.

[5]. Chouaïbou, M.S., Fodjo, B.K., Fokou, G., Allassane, O.F., Koudou, B.G., David, J.-P., Antonio-Nkondjio, C., Ranson, H., Bonfoh, B., (2016). Influence of the agrochemicals used for rice and vegetable cultivation on insecticide resistance in malaria vectors in southern Côte d'Ivoire. Malar. J. 15, 426. https://doi.org/10.1186/s12936-016-1481-5.

[6]. Darko, G., Acquaah, S.O., (2008). Levels of organochlorine pesticides residues in dairy products in Kumasi, Ghana. Chemosphere 71, 294-298. https://doi.org/10.1016/j.chemosphere.2007.09.005

[7]. Darko, G., Addai Tabi, J., Adjaloo, M.K., Borquaye, L.S., (2017). Pesticide Residues in Honey from the Major Honey Producing Forest Belts in Ghana. J. Environ. Public Health 2017, 7957431. https://doi.org/10.1155/2017/7957431.

[8]. Darko, G., Akoto, O., (2008). Dietary intake of organophosphorus pesticide residues through vegetables from Kumasi, Ghana. Food Chem. Toxicol. Int. J. Publ. Br. Ind. Biol. Res. Assoc. 46, 3703-3706. https://doi.org/10.1016/j.fct.2008.09.049.

[9]. Di Bella, G., Haddaoui, I., Lo Turco, V., Potortì, A.G., Fede, M.R., Dugo, G., (2017). POP levels in beans from Mediterranean and tropical areas. J. Sci. Food Agric. 97, 2610-2616. https://doi.org/10.1002/jsfa.8083

[10]. Ekhator, O.C., Udowelle, N.A., Igbiri, S., Asomugha, R.N., Igweze, Z.N., Orisakwe, O.E., (2017). Safety Evaluation of Potential Toxic Metals Exposure from Street Foods Consumed in Mid-West Nigeria. J. Environ. Public Health 2017. https://doi.org/10.1155/2017/8458057.

[11]. EPA Bans 25 Dangerous Agro-Chemicals, (2008). Mod. Ghana. URL https://www.modernghana.com/news/180428/epa-bans-25-dangerous-agro-chemicals.html (accessed 2.27.18).

[12]. Essumang, D.K., Asare, E.A., Dodoo, D.K., (2013). Pesticides residues in okra (non-target crop) grown close to a watermelon farm in Ghana. Environ. Monit. Assess. 185, 7617-7625. https://doi.org/10.1007/s10661013-3123-5.

[13]. Fosu, P.O., Donkor, A., Ziwu, C., Dubey, B., Kingsford-Adaboh, R., Asante, I., Nyarko, S., Tawiah, R., Nazzah, N., (2017). Surveillance of pesticide residues in fruits and vegetables from Accra Metropolis markets, Ghana, 2010-2012: a case study in Sub-Saharan Africa. Environ. Sci. Pollut. Res. Int. 24, 17187-17205. https://doi.org/10.1007/s11356-017-9287-8.

[14]. Harrison, R.M., Chirgawi, M.B., (1989). The assessment of air and soil as contributors of some trace metals to vegetable plants. I. Use of a filtered air growth cabinet. Sci. Total Environ. 83, 13-34.

[15]. Johnson, L.A., Welch, B., Whitfield, S.M., (2013). Interactive effects of pesticide mixtures, predators, and environmental regimes on the toxicity of two pesticides to red-eyed tree frog larvae. Environ. Toxicol. Chem. 32, 2379-2386. https://doi.org/10.1002/etc.2319. 
DOI: $10.21522 /$ TIJPH.2013.06.03.Art018

ISSN: $2520-3134$

[16]. Kimaru, H.P.N.I.W., (2014). GC-MS Analysis of an Herbal Medicinal Remedy to Identify Potential Toxic Compounds

http://www.chromatographyonline.com/gc-ms-analysis-herbal-medicinal-remedy-identify-potential-toxiccompounds-0 (accessed 3.12.18).

[17]. Kuranchie-Mensah, H., Yeboah, P.O., Nyarko, E., Golow, A.A., (2013). Studies on organochlorine pesticide residue in fishes from the Densu river basin, Ghana. Bull. Environ. Contam. Toxicol. 90, 421-426. https://doi.org/10.1007/s00128-012-0931-1.

[18]. Mosaddegh, M.H., Emami, F., Asghari, G., (2014). Evaluation of Residual Diazinon and Chlorpiryfos in Children Herbal Medicines by Headspace-SPME and GC-FID. Iran. J. Pharm. Res. IJPR 13, 541-549.

[19]. Naithani, V., Kakkar, P., (2004). An evaluation of residual organochlorine pesticides in popular Indian herbal teas. Arch. Environ. Health 59, 426-430. https://doi.org/10.3200/AEOH.59.8.426-430.

[20]. Ngoula, F., Watcho, P., Dongmo, M.-C., Kenfack, A., Kamtchouing, P., Tchoumboué, J., (2007). Effects of pirimiphos-methyl (an organophosphate insecticide) on the fertility of adult male rats. Afr. Health Sci. 7, 3-9. https://doi.org/10.5555/afhs.2007.7.1.3.

[21]. Obiri-Danso, K., Adonadaga, M.G., Hogarh, J.N., (2011). Effect of agrochemical use on the drinking water quality of Agogo, a tomato growing community in Ashanti Akim, Ghana. Bull. Environ. Contam. Toxicol. 86, 71-77. https://doi.org/10.1007/s00128-010-0183-x.

[22]. Oh, C.-H., (2009). Monitoring of residual pesticides in herbal drug materials of Korea and China. Bull. Environ. Contam. Toxicol. 82, 639-643. https://doi.org/10.1007/s00128-009-9649-0.

[23]. Osei-Fosu, P., Donkor, A.K., Nyarko, S., Nazzah, N.K., Asante, I.K., Kingsford-Adabo, R., Arkorful, N.A., (2014). Monitoring of pesticide residues of five notable vegetables at Agbogbloshie market in Accra, Ghana. Environ. Monit. Assess. 186, 7157-7163. https://doi.org/10.1007/s10661-014-3917-0.

[24]. Ou, X., Wang, L., Guo, L., Cui, X., Liu, D., Yang, Y., (2016). Soil-Plant Metal Relations in Panax notoginseng: An Ecosystem Health Risk Assessment. Int. J. Environ. Res. Public. Health 13. https://doi.org/10.3390/ijerph13111089.

[25]. Pubchem, n.d. Chlorpyrifos-methyl [WWW Document]. URL https://pubchem.ncbi.nlm.nih.gov/compound/21803 (accessed 7.20.18).

$\begin{array}{llll}\text { [26]. Pubchem, n.d. Pirimiphos-methyl } & \text { [WWW }\end{array}$ https://pubchem.ncbi.nlm.nih.gov/compound/34526 (accessed 7.20.18).

[27]. Pubchem, n.d. Fenitrothion [WWW Document]. URL https://pubchem.ncbi.nlm.nih.gov/compound/31200 (accessed 7.20.18).

[28]. Skovgaard, M., Renjel Encinas, S., Jensen, O.C., Andersen, J.H., Condarco, G., Jørs, E., (2017). Pesticide Residues in Commercial Lettuce, Onion, and Potato Samples From Bolivia-A Threat to Public Health? Environ. Health Insights 11. https://doi.org/10.1177/1178630217704194.

[29]. Wang, X., Sato, T., Xing, B., Tao, S., (2005). Health risks of heavy metals to the general public in Tianjin, China via consumption of vegetables and fish. Sci. Total Environ. 350, 28-37. https://doi.org/10.1016/j.scitotenv.2004.09.044.

[30]. Yang, W.-Z., Kang, C.-Z., Ji, R.-F., Zhou, L.I., Wang, S., Li, Z.-H., Ma, Z.-H., Guo, L.-P., (2017). [Situation analysis and standard formulation of pesticide residues in traditional Chinese medicines]. Zhongguo Zhong Yao Za Zhi Zhongguo Zhongyao Zazhi China J. Chin. Mater. Medica 42, 2284-2290. 